\title{
Synthetic Human Parathyroid Hormone-like Protein Stimulates Bone Resorption and Causes Hypercalcemia in Rats
}

\author{
Andrew F. Stewart, Marguerite Mangin, Terence Wu, Douglas Goumas, Karl L. Insogna, \\ William J. Burtis, and Arthur E. Broadus \\ Departments of Endocrinology, The West Haven Veterans Administration Medical Center, West Haven, Connecticut 06516; \\ and Yale University School of Medicine, New Haven, Connecticut 06510
}

\begin{abstract}
Parathyroid hormone-like adenylate cyclase-stimulating proteins (hACSPs) have been implicated as one of the calcemic, bone-resorbing agents in patients with humoral hypercalcemia of malignancy. We report the synthesis of an amino-terminal hACSP fragment, Tyr $^{36}$ hACSP (1-36) amide. The synthetic hACSP is a potent agonist of renal membrane adenylate cyclase $\left(K_{\mathrm{m}}, 1.7 \times 10^{-10}\right)$ and of bone cell adenylate cyclase $\left(K_{\mathrm{m}} 1\right.$ $\left.\times 10^{-9} \mathrm{M}\right)$. It is a potent bone-resorbing agent in vitro, stimulating ${ }^{45} \mathrm{Ca}$ release from fetal rat long bones at a concentration of $10^{-9} \mathrm{M}$. When infused via osmotic minipumps into rats, it is also a potent calcemic factor in vivo, inducing a rise in serum calcium from (mean \pm SD) $10.6 \pm 0.6$ to $19.7 \pm 3.2 \mathrm{mg} / \mathrm{dl}$ when infused at $1.4 \mu \mathrm{g} / \mathrm{h}$ and from $9.9 \pm 0.7$ to $11.4 \pm 1.2$ $\mathrm{mg} / \mathrm{dl}$ when infused at $0.14 \mu \mathrm{g} / \mathrm{h}$.

These findings indicate that biologically active hACSP fragments can be synthesized. One such synthetic peptide possesses the in vitro and in vivo bioactivities demonstrated in native, tumor-derived hACSPs. It is also a potent calcemic, bone-resorbing agent.
\end{abstract}

\section{Introduction}

Tumors derived from patients with humoral hypercalcemia of malignancy $(\mathrm{HHM})^{1}$ contain a family of adenylate cyclasestimulating proteins (hACSPs) which mimic certain actions of PTH (1-10). PTH-like hACSPs derived from human and animal tumors have been shown to stimulate adenylate cyclase in bone, kidney, and dermal cells, and to stimulate adenylate cyclase through an interaction with PTH receptors. These peptides appear to exist in a high $(\sim 17,000 \mathrm{~mol} \mathrm{wt})$ and a low $(7,000-9,000 \mathrm{~mol} \mathrm{wt})$ form $(6-10)$. We $(6,7)$ and others $(8,9)$ have purified hACSPs from a variety of HHM-associated tumors. Amino-terminal amino acid sequencing of these pep-

Address correspondence to Dr. Stewart, Research/151, West Haven VA Medical Center, West Spring St., West Haven, CT 06516.

Received for publication 11 September 1987 and in revised form 20 November 1987.

1. Abbreviations used in this paper: bPTH, bovine PTH; hACSP, human adenylate cyclase-stimulating proteins; HHM, humoral hypercalcemia of malignancy; ROS, rat osteosarcoma; T/C ratio, ratio of ${ }^{45} \mathrm{Ca}$ release by treated as compared with control bones; TPTX, thyroparathyroidectomized.

The Journal of Clinical Investigation, Inc.

Volume 81, February 1988, 596-600 tides indicates that the peptides have a common sequence, and that intense homology exists between the amino termini of hACSPs and of human PTH. Recently, the molecular cloning of cDNA derived from two HHM-associated human cancers has been described, elucidating the full amino acid sequence of the parent hACSP molecule $(11,12)$. This should permit the synthesis of a variety of biologically active hACSP-related peptides. We now report that one such synthetic peptide is potent agonist of adenylate cyclase stimulation and bone resorption in vitro, and induces hypercalcemia in vivo when infused into rats.

\section{Methods}

Peptides. The 36 amino acid peptide shown in Fig. 1, $\mathrm{Tyr}^{36} \mathrm{hACSP}$ (1-36) amide (4,292 mol wt), was synthesized using a 430A solid-phase peptide synthesizer (Applied Biosystems, Foster City, CA) with a loading capacity of $0.5 \mathrm{mmol}$. The synthetic peptide was clcaved with hydrogen fluoride and purified using a preparative scale Vydac octadecyl reversed-phase column (Separations Group, Hesperia, CA). 53 $\mathrm{mg}$ of peptide were synthesized as assessed by amino acid analysis. A tyrosine residue was substituted for the naturally occurring isoleucine at position 36 so that the peptide could be iodinated. Synthetic bovine PTH (bPTH) (1-34) was purchased from Bachem Inc., Torrance, CA.

Adenylate cyclase assays. Adenylate cyclase-stimulating activity was examined in two assay systems. One was a guanyl nucleotide-amplified canine renal cortical membrane PTH-sensitive adenylate cyclase assay, performed as previously described in detail (1). Briefly, synthetic peptide or bPTH (1-34) standard (Bachem Inc.) was added in duplicate to assay tubes containing partially purified canine renal cortical membranes, and the conversion of alpha- $\left[{ }^{32} \mathrm{P}\right] \mathrm{ATP}$ to $\left[{ }^{32} \mathrm{P}\right] \mathrm{CAMP}$ was examined. Results are expressed as the percent increment in adenylate cyclase activity in tubes containing the peptides as compared with tubes containing vehicle only. The results shown in Fig. $2 \mathrm{~A}$ are representative of two separate assays.

Adenylate cyclase-stimulating activity was also examined using the PTH-sensitive rat osteosarcoma (ROS) line 17/2.8. This assay has also been described in detail $(3,4,13,14)$. This assay differs from the renal membrane assay in that it uses bone tissue as compared with renal tissue and utilizes whole cells as compared with cell membranes. Briefly, synthetic peptides were added to duplicate wells containing confluent ROS $17 / 2.8$ cells which had been prelabeled with $\left[{ }^{3} \mathrm{H}\right]$ adenine, and were incubated at $37^{\circ} \mathrm{C}$ for $10 \mathrm{~min}$ in $5 \% \mathrm{CO}_{2}$. Adenylate cyclase activity (production of $\left[{ }^{3} \mathrm{H}\right] \mathrm{cAMP}$ ) is expressed, as in the renal assay, as the percent increment in CAMP production over basal. The results shown in Fig. $2 B$ are representative of three assays.

Fetal bone resorption assay. This assay is a modification of the method of Raisz (15) and has been described in detail $(14,16,17)$. The assay uses ${ }^{45} \mathrm{Ca}$-labeled fetal rat long bones (radius and ulna), a 24-h preincubation period, and a 72-h sample incubation. Synthetic peptides were examined in the concentrations shown in Fig. 3, in at least 


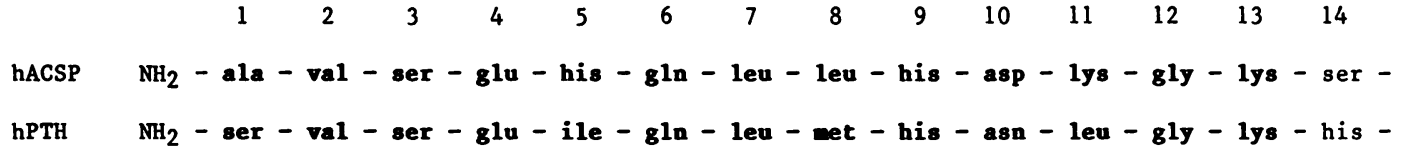

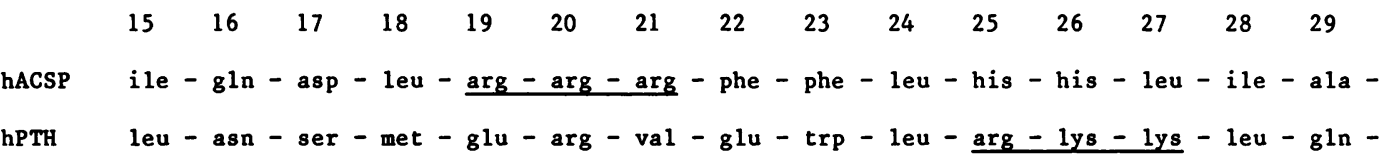

$\begin{array}{lllllll}30 & 31 & 32 & 33 & 34 & 35 & 36\end{array}$

hACSP

glu - ile - his - thr - ala - glu - tyr-amide

hPTH
Figure 1. Amino acid sequences of $\mathrm{Tyr}^{36} \mathrm{hACSP}$ (1-36) amide and of hPTH (1-34). The boldlettered amino acids indicate the regions of homology between the two peptides. The underlined regions are tribasic regions that may be related to receptor binding. bPTH has an alanine in position 1. eight pairs of bones. Basal ${ }^{45} \mathrm{Ca}$ release was $( \pm \mathrm{SD}) 4.9 \pm 0.9 \%$. Results are expressed as the ratio of ${ }^{45} \mathrm{Ca}$ release by treated as compared with control bones ( $\mathrm{T} / \mathrm{C}$ ratio).

Studies in vivo. Tyr $^{36} \mathrm{hACSP}(1-36)$ amide was diluted in $150 \mathrm{mM}$ sodium chloride containing $2 \%$ cysteine- $\mathrm{HCl}$ (Sigma Chemical Co., St. Louis, MO), pH 1.5, as described by Ibrahim et al. (18), and was loaded into osmotic minipumps (model 2001; Alza Corp., Palo Alto, CA), such that a delivery rate of 0.14 or $1.4 \mu \mathrm{g}$ peptide $/ \mu \mathrm{l}$ per $\mathrm{h}$ (as indicated in Fig. 4) was achieved. The pumps were implanted subcutaneously under methoxyflurane anesthesia into the scapular region of female 6-8-wk Wistar-Furth rats (Charles River Breeding Laboratories, Inc., Wilmington, MA), allowed to pump for $3 \mathrm{~d}$, and then removed. Serum calcium and phosphorus concentrations from each day of infusion, and for the $3 \mathrm{~d}$ after the infusion, were measured. Blood was obtained via tail vein. Serum calcium and phosphorus were determined by atomic absorption spectrophotometry, and by the method of Fiske and Subbarow, respectively.

Statistical analysis. Statistical analysis of the fetal bone resorption assay results and the in vivo $\mathrm{Tyr}^{36} \mathrm{hACSP}(1-36)$ amide infusion study was performed using Dunnett's Test.

\section{Results}

Renal adenylate cyclase-stimulating activity induced by the synthetic hACSP fragment is shown in Fig. $2 \mathrm{~A}$. In this assay, the synthetic peptide produced a dose-response curve parallel to that of bPTH (1-34). In this system, Tyr ${ }^{36}$ hACSP (1-36) amide displayed a $K_{\mathrm{m}}$ of $1.7 \times 10^{-10} \mathrm{M}$, while bPTH (1-34) had a $K_{\mathrm{m}}$ of $4 \times 10^{-11} \mathrm{M}$. Since the molecular weights of $\mathrm{Tyr}^{36}$
hACSP (1-36) amide and bPTH (1-34) are approximately equivalent $(4,292$ vs. 4,106$), \operatorname{Tyr}^{36}$ hACSP (1-36) amide has a specific activity on both a weight and molar basis approximately one-quarter that of bPTH (1-34).

Results obtained using the ROS $17 / 2.8$ assay are shown in Fig. $2 B$. In this system the dose responses of the two peptides are also parallel. The $K_{\mathrm{m}}$ values for the hACSP analogue and for bPTH (1-34) were both $\sim 1 \times 10^{-9} \mathrm{M}$, indicating that the two peptides are approximately equipotent in this bone-derived system.

In vitro bone resorption is demonstrated in Fig. 3. Tyr $^{36}$ hACSP (1-36) amide induces a definite resorptive response at a concentration of $1 \times 10^{-9} \mathrm{M}$ and displays maximal resorption at $1 \times 10^{-7} \mathrm{M}$. bPTH (1-34) induced statistically significant bone resorption at a concentration $1 \times 10^{-9} \mathrm{M}$ and achieved maximal resorption at $1 \times 10^{-7} \mathrm{M}$. While precise quantitation of potency in the fetal bone resorption assay is difficult to achieve, it would appear that $\mathrm{Tyr}^{36} \mathrm{hACSP}(1-36)$ amide is approximately equipotent with bPTH (1-34) in this system.

The results of in vivo osmotic minipump infusion of $\mathrm{Tyr}^{36}$ hACSP (1-36) amide are shown in Fig. 4. Rats infused with the larger dose $(1.4 \mu \mathrm{g} / \mathrm{h})$ were normocalcemic at the outset of the study, became profoundly hypercalcemic by day 3 , and returned to their normocalcemic baseline after discontinuation of infusion of the peptide. Rats infused with the lower dose $(0.14 \mu \mathrm{g} / \mathrm{h})$ displayed mild but statistically significant increases in serum calcium on day 3 (Fig. 4).
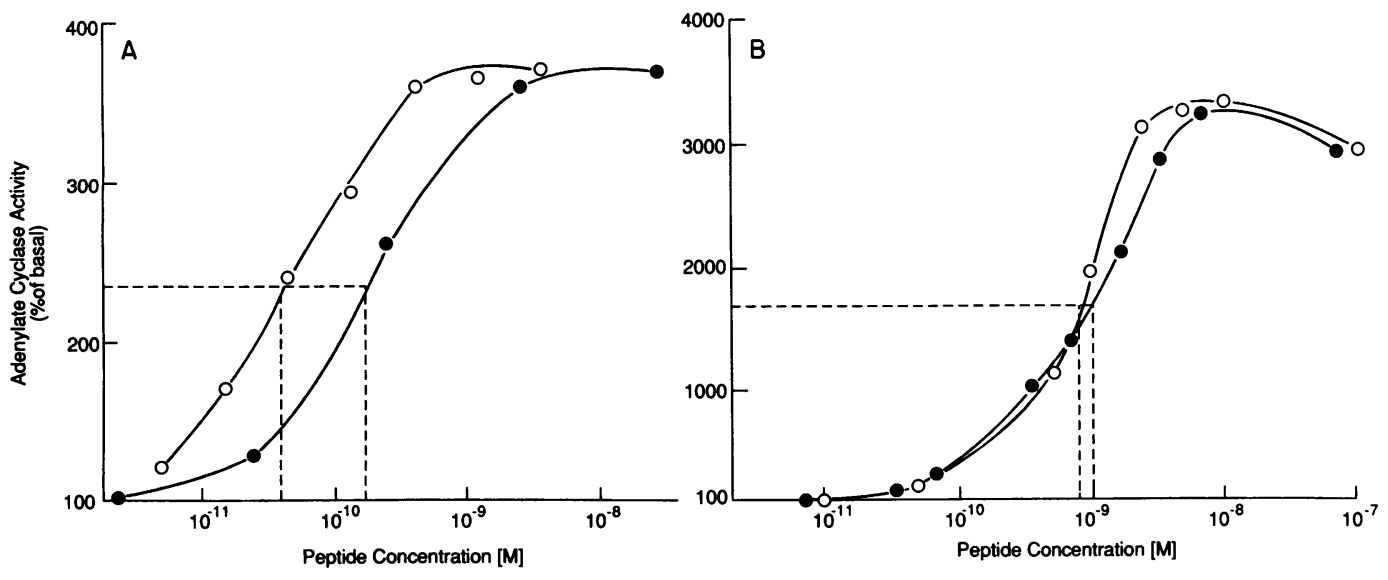

Figure 2. Renal adenylate cyclase activity $(A)$ and bone cell adenylate cyclase activity $(B)$ produced by bPTH (1-34) (open circles) and by Tyr $^{36}$ hACSP (1-36) amide (closed circles). The dotted line in each figure indicates the point of half-maximal stimulation. 

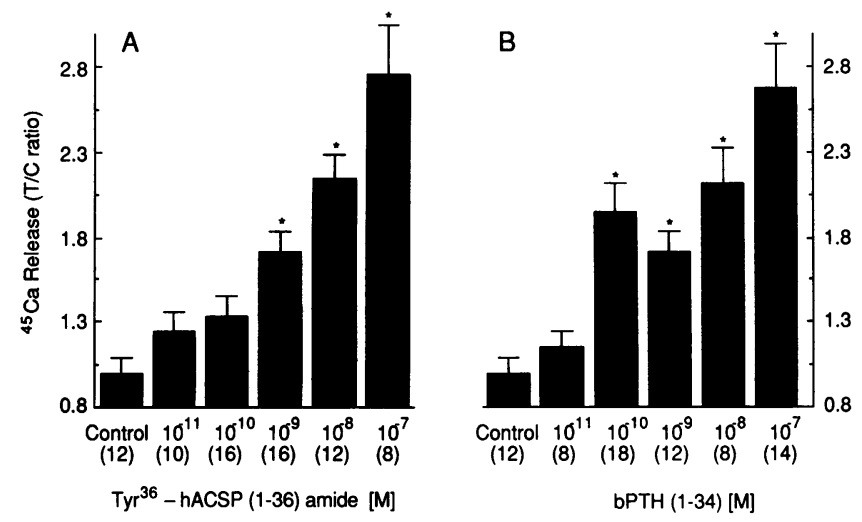

Figure 3. In vitro bone resorption produced by $\mathrm{Tyr}^{36} \mathrm{hACSP}(1-36)$ amide $(A)$ and by bPTH (1-34) $(B)$. The peptides were added to wells in the molar concentrations indicated. $\mathrm{T} / \mathrm{C}$ ratio is the ratio of ${ }^{45} \mathrm{Ca}$ release in treated as compared with control bones. Bars indicate standard error of the mean. The numbers in parentheses below the bars indicate the number of bone pairs examined. An asterisk (*) indicates $P<0.05$ as compared with control bones.

Serum phosphorus values in rats receiving $1.4 \mu \mathrm{g} / \mathrm{h}$ of the synthetic peptide were significantly lower $(P<0.01)$ on days 2 and 3 of the infusion (mean $\pm \mathrm{SD}, 6.3 \pm 0.3$ and $6.7 \pm 0.2$ $\mathrm{mg} / \mathrm{dl}$, respectively) than on day $0(9.5 \pm 1.3)$. The serum phosphorus concentration in rats receiving the lower dose of synthetic peptide $(0.14 \mu \mathrm{g} / \mathrm{h})$ fell to $8.1 \pm 1.6 \mathrm{mg} / \mathrm{dl}$ on day 3 , but this change did not achieve statistical significance.

\section{Discussion}

We report the synthesis of a synthetic peptide fragment based upon the cDNA-predicted amino acid sequence of human $\operatorname{ACSP}(11,12)$. Since the circulating hACSP form(s) that occur under normal physiological conditions and in patients with HHM is unknown, the choice of length of this synthetic peptide was arbitrary. The full-length sequence of PTH (1-84) contains no obvious cleavage site in the region of the phenylalanine at position 34 . Similarly, the cDNA-predicted hACSP sequence contains no obvious cleavage sites in the region of amino acids 20 through 50 . Based on the observations that

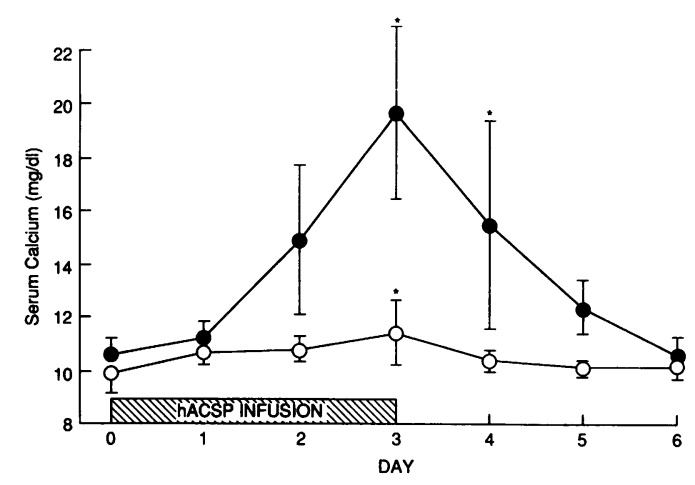

Figure 4. Effect of a 3-d infusion of $\mathrm{Tyr}^{36} \mathrm{hACSP}$ (1-36) amide on serum calcium in rats. Each data point is the mean of serum calcium determinations obtained from four rats. The open circles indicate the response to $1.4 \mu \mathrm{g} / \mathrm{h}$ and the closed circles the response to $0.14 \mu \mathrm{g} / \mathrm{h}$. An asterisk (*) indicates $P<0.05$ as compared with day 0 values.
hACSPs contain striking $\mathrm{NH}_{2}$-terminal sequence homology with PTH and that the two amino-terminal amino acids of PTH are critical for adenylate cyclase stimulation $(19,20)$, the $\mathrm{NH}_{2}$-terminal of the peptide was synthesized. The tribasic triplet arginine-19 to arginine-21 was included because of its structural analogy to the tribasic putative receptor-binding region of PTH, amino acids 25 through 27 (19) (Fig. 1). The length, 36 amino acids, was selected because it is similar to the biologically active 1-34 synthetic fragment of PTH and because there is a hydrophobic amino acid (isoleucine) at position 36 , which, it was hoped, would permit a terminal tyrosine substitution with little influence on bioactivity, but would facilitate iodination of the peptide. A terminal amide functionality was added in place of a carboxyl group, based on the observation that synthetic PTH constructs ending in tyrosineamide are more potent than those ending in tyrosine alone (19). Note that the considerations described above are arbitrary, and that the physiological relevance of the synthetic peptide to the circulating hACSP forms and to the previously reported 17,000- and 6,000-9,000-mol-wt forms is unknown.

With these considerations in mind, the important observation described in this report is that the synthetic hACSP fragment possesses five of the cardinal bioactivities required of any synthetic hACSP or putative hHHM factor. Patients with HHM are characterized by increases in nephrogenous cAMP excretion (21), and tumors associated with HHM contain and/or secrete protein factors that stimulate PTH-sensitive adenylate cyclase systems in vitro (1-10). For example, the 17,000-mol-wt hACSP purified by this laboratory maximally stimulated a canine renal cortical adenylate cyclase system, with a specific activity, on a weight basis, of approximately one-sixth that of bPTH (1-34) or, on a molar basis, two thirds that of bPTH (1-34) (6). The synthetic peptide described herein also maximally stimulates renal cortical adenylate cyclase. The specific activity of the synthetic peptide on a weight or molar basis is comparable with that described for the native tumor-derived hACSP, being approximately one-quarter that of PTH.

HHM-associated tumor extracts and conditioned medium have also been reported to stimulate adenylate cyclase via interaction with the PTH receptor in clonal rat osteosarcoma cells $(3,6,8,17,22)$. In contrast to the renal adenylate cyclase system, potency of these tumor-derived hACSP preparations in clonal ROS cells has usually exceeded that of PTH. As observed with native hACSP preparations when compared with bPTH (1-34), synthetic $\mathrm{Tyr}^{36}$ hACSP (1-36) amide is more potent in the osteosarcoma assay than in the renal adenylate cyclase system (Fig. 2). Direct comparison of the potency of the synthetic peptide to purified native hACSPs in this system will require further study.

Bone biopsies obtained from patients with HHM reveal dramatic increases in osteoclastic bone resorption $(23,24)$, and partially purified HHM-derived tumor extracts and conditioned medium contain factors that stimulate bone resorption in vitro $(3,16,17,25)$. While bone-resorbing activity and adenylate cyclase-stimulating activity co-migrate under a variety of chromatographic conditions, it is uncertain whether the bone-resorbing activity identified in these partially purified materials is derived from the hACSP, or whether it results from unrelated co-migrating peptides. We have observed that the purified synthetic hACSP fragment, free of tumor-derived contaminants, is a potent bone-resorbing agent. The potency 
of the synthetic peptide compares favorably with that of bPTH (1-34) (Fig. 3), and with figures reported for other bone-resorbing agents such as transforming growth factor-alpha (26), interleukin 1 (27), tumor necrosis factor-alpha (28), epidermal growth factor (29), and tumor necrosis factor-beta (30). Definition of the precise potency of the factor as compared with PTH and to native tumor-derived hACSPs will require further study, but it is clear that when compared with other reported bone-resorbing agents $(17,25-29)$ the synthetic peptide is potent.

Hypercalcemia is the prime feature that identifies patients with HHM. This hypercalcemia is due in large part to bone resorption $(21,23,24)$ and may have a renal (reabsorptive) component in selected patients $(31,32)$. Thus, hACSPs and any other putative HHM factor must be capable of inducing hypercalcemia in intact animals. The magnitude of the hypercalcemia observed in the animals infused with $\mathrm{Tyr}^{36} \mathrm{hACSP}$ (1-36) amide was dramatic, with three of the four animals infused with the high dose-developing calcium values of 21 $\mathrm{mg} / \mathrm{dl}$ or greater by the 3rd day of the infusion. By way of comparison, in one report, acute injection of $5 \mathrm{U}(\sim 0.8 \mu \mathrm{g})$ of hPTH (1-34) along with $\mathrm{CaCl}_{2}$ into thyroparathyroidectomized (TPTX) rats induced a rise in the serum calcium of 1.2 $\mathrm{mg} / \mathrm{dl}$ (33). In a second report, acute infusion of $1.0 \mu \mathrm{g}$ of bPTH (1-84) into TPTX rats induced a rise in the serum calcium from $\sim 6-8 \mathrm{mg} / \mathrm{dl}$ (34). In a third report, the design of which most closely approximates the current design, hypocalcemic TPTX rats infused by osmotic minipumps with bPTH (1-34) at a rate of $0.5 \mu \mathrm{g} / \mathrm{h}$ developed hypercalcemia (13-15 $\mathrm{mg} / \mathrm{dl}$ ) by day $3(18)$. Animals infused with $0.17 \mu \mathrm{g} / \mathrm{h}$ developed hypercalcemia in the $11.0-\mathrm{mg} / \mathrm{dl}$ range, and animals receiving $0.6 \mu \mathrm{g} / \mathrm{h}$ showed no calcemic response. While more extensive studies will need to be done to define the in vivo calcemic potency of $\mathrm{Tyr}^{36} \mathrm{hACSP}(1-36)$ amide in relation to PTH, the marked hypercalcemia that is induced by the synthetic peptide and the small dose of peptide required to induce hypercalcemia (0.14 vs. $0.17 \mu \mathrm{g} / \mathrm{h}$ for bPTH [1-34] [18]), indicate that it is a very potent calcemic hormone.

Patients with HHM display hypophosphatemia and reductions in the renal phosphorus threshold (21). Marked hypophosphatemia was observed on days 2 and 3 of the infusion with the synthetic peptide. The likelihood that this hypophosphatemia was induced through a reduction in the renal phosphorus threshold is supported by the observations that the synthetic peptide also inhibits phosphate uptake in cultured renal cells (35).

These studies indicate that synthetic $\mathrm{Tyr}^{36}$ hACSP (1-36) amide stimulates adenylate cyclase in two systems, stimulates bone resorption in vitro, induces hypercalcemia and hypophosphatemia in vivo, and that responses are observed in doses that are similar to those required of bPTH (1-34). More extensive studies are clearly required to completely and directly compare the potency and effects of the synthetic hACSP with those of bPTH and to native, tumor-derived hACSPs. Such studies are currently in progress. The findings described in the current report provide strong support for the thesis that hACSPs may be the factor responsible for HHM, and indicate that synthetic analogues of native hACSP will be useful reagents in studies examining the effects of hACSPs on target tissues, in defining the normal role(s) of hACSPs in nonmalignant tissues, and in studying structure-function relations.

\section{Acknowledgments}

The authors thank Dr. Kenneth Williams and the Protein Sequencing and Synthesis Facility at Yale University School of Medicine for synthesizing the peptide described. We thank Mrs. Ann Blood for expert secretarial assistance and Mr. C. F. Stewart for technical assistance.

This work was supported by the Veterans Administration and by National Institutes of Health grant AR-30102.

\section{References}

1. Stewart, A. F., K. L. Insogna, D. Goltzman, and A. E. Broadus. 1983. Identification of adenylate cyclase-stimulating activity and cytochemical bioactivity in extracts of tumors from patients with humoral hypercalcemia of malignancy. Proc. Natl. Acad. Sci. USA. 80:14541458.

2. Strewler, G. J., R. D. Williams, and R. A. Nissenson. 1983. Human carcinoma cells produce hypercalcemia in the nude mouse and a novel protein recognized by parathyroid hormone receptors. $J$. Clin. Invest. 71:769-774.

3. Rodan, S. B., K. L. Insogna, A. M. Vignery, A. F. Stewart, A. E. Broadus, S. M. D'Souza, D. R. Bertolini, G. R. Mundy, and G. A. Rodan. 1983. Factors associated with humoral hypercalcemia of malignancy stimulate adenylate cyclase in osteoblastic cells. J. Clin. Invest. 72:1511-1515.

4. Wu, T. L., K. L. Insogna, L. Milstone, and A. F. Stewart. 1987. Skin-derived fibroblasts respond to human PTH-like adenylate cyclase-stimulating proteins. J. Clin. Endocrinol. Metab. 65:105-109.

5. Silve, C., A. Santora, and A. Spiegel. 1985. A factor produced by cultured rat leydig cell tumor cells associated with humoral hypercalcemia of malignancy stimulates $3^{\prime}, 5^{\prime}$-monophosphate production via the parathyroid hormone receptor in human skin fibroblasts. J. Clin. Endocrinol. Metab. 60:1144-1147.

6. Burtis, W. J., T. Wu, C. Bunch, J. J. Wysolmerski, K. L. Insogna, A. E. Broadus, and A. F. Stewart. 1987. Identification of a novel 17,000 dalton PTH-like adenylate cyclase-stimulating protein from a tumor associated with humoral hypercalcemia of malignancy. J. Biol. Chem. 262:7151-7156.

7. Stewart, A. F., T. Wu, D. Goumas, W. J. Burtis, and A. E. Broadus. 1987. N-terminal amino acid sequence of two novel tumorderived adenylate cyclase-stimulating proteins: identification of parathyroid hormone-like and parathyroid hormone-unlike domains. Biochem. Biophys. Res. Commun. 146:672-678.

8. Moseley, J. M., M. Kubota, H. Diefenbach-Jagger, R. E. H. Wettenhall, B. E. Kemp, L. J. Sura, C. P. Rodda, P. R. Ebeling, P. J. Hudson, J. D. Zajac, and T. J. Martin. 1987. Parathyroid hormonerelated protein purified from a human lung cancer line. Proc. Natl. Acad. Sci. USA. 84:5048-5052.

9. Nissenson, R., S. Leung, D. Diep, R. Williams, and G. Strewler. 1987. Purification of a low molecular weight form of the tumor-derived parathyroid hormone-like protein. J. Bone Min. Res. 2(Suppl):390 Abstract.

10. Stewart, A. F., W. J. Burtis, T. Wu, D. Goumas, and A. E. Broadus. 1987. Two forms of parathyroid hormone-like adenylate cyclase-stimulating protein derived from tumors associated with humoral hypercalcemia of malignancy. J. Bone Min. Res. 2:587-593.

11. Mangin, M., A. C. Webb, B. E. Dreyer, J. T. Possillico, K. Ikeda, E. C. Weir, A. F. Stewart, N. H. Bander, L. Milstone, D. E. Barton, U. Francke, and A. E. Broadus. 1987. Identification of a complementary DNA encoding a parathyroid hormone-like peptide from a human tumor associated with humoral hypercalcemia of malignancy. Proc. Natl. Acad. Sci. USA. In press.

12. Suva, L. J., G. A. Winslow, R. Wettenhall, R. G. Hammonds, J. M. Mosely, H. Diefenbach-Jagger, C. P. Rodda, B. E. Kemp, H. Rodriguez, E. Y. Chen, P. J. Hudson, T. J. Martin, and W. I. Wood. 
1987. A parathyroid hormone-related protein implicated in malignant hypercalcemia: cloning and expression. Science (Wash. DC). 237:893-896.

13. Merendino, J. J., K. L. Insogna, L. M. Milstone, A. E. Broadus, and A. F. Stewart. 1986. Cultured human keratinocytes produce a parathyroid hormone-like protein. Science (Wash. DC). 231:388-390.

14. Insogna, K., E. Weir, T. Wu, A. Stewart, A. Broadus, L. Milstone, and M. Centrella. 1987. Co-purification of transforming growth factor beta-like activity with PTH-like and bone-resorbing actitivities from a tumor associated with humoral hypercalcemia of malignancy. Endocrinology. 120:2183-2185.

15. Raisz, L. G. 1965. Bone resorption in tissue culture factors influence the response to parathyroid hormone. J. Clin. Invest. 44:103-116.

16. Stewart, A. F., K. L. Insogna, W. J. Burtis, A. Aminiafshar, T. $\mathrm{Wu}$, and A. E. Broadus. Frequency and partial characterization of adenylate cyclase-stimulating activity in tumors associated with humoral hypercalcemia of malignancy. J. Bone Min. Res. 1:267-276.

17. Stewart, A. F., T. Wu, W. J. Burtis, E. C. Weir, A. E. Broadus, and K. L. Insogna. 1987. The relative potency of a human tumor-derived PTH-like adenylate cyclase-stimulating preparation in three bioassays. J. Bone Min. Res. 2:37-43.

18. Ibrahim, M. M., L. R. Forte, and M. L. Thomas. 1982. Maintenance of normocalcemia by continuous infusion of synthetic bovine parathyroid hormone (1-34) in parathyroidectomized rats. Calcif. Tissue Int. 34:553-557.

19. Habener, J. F., M. Rosenblatt, and J. T. Potts. 1984. Parathyroid hormone: biochemical aspects of biosynthesis, secretion, action, and metabolism. Physiol. Rev. 64:985-1052.

20. Rosenblatt, M., E. N. Callahan, J. E. Mahaffey, A. Pont, and J. T. Potts. 1977. Parathyroid hormone inhibitors: design, synthesis, and biologic evaluation of hormone analogues. J. Biol. Chem. 252:5847-5851.

21. Stewart, A. F., R. Horst, L. J. Deftos, E. C. Cadman, R. Lang, and A. E. Broadus. 1980. Biochemical evaluation of patients with cancer-associated hypercalcemia: evidence for humoral and non-humoral groups. N. Engl. J. Med. 303:1377-1383.

22. Nissenson, R. A., G. J. Strewler, R. D. Williams, and S. C. Leung. 1985. Activation of the parathyroid hormone receptor-adenylate cyclase system in osteosarcoma cells by a human renal carcinoma factor. Cancer Res. 45:5358-5363.

23. Stewart, A. F., A Vignery, A. Silvergate, N. D. Ravin, V. LiVolsi, A. E. Broadus, and R. Baron. 1982. Quantitative bone histomorphometry in humoral hypercalcemia of malignancy: uncoupling of bone cell activity. J. Clin. Endocrinol. Metab. 55:219-227.

24. Sharp, C. F., R. K. Rude, R. Terry, and F. R. Singer. 1982.
Abnormal bone and parathyroid histology in carcinoma patients with pseudohyperparathyroidism. Cancer. 49:1449-1455.

25. Klein, R. F., G. J. Strewler, S. C. Leung, and R. A. Nissenson. 1987. Parathyroid hormone-like adenylate cyclase-stimulating activity from a human carcinoma is associated with bone-resorbing activity. Endocrinology. 120:504-511.

26. Stern, P. H., N. S. Krieger, R. A. Nissenson, R. D. Williams, M. E. Winkler, R. Derynck, and G. J. Strewler. 1985. Human transforming growth factor alpha stimulates bone resorption in vitro. $J$. Clin. Invest. 76:2016-2019.

27. Dewhirst, F. E., P. P. Stashenko, J. E. Mole, and T. Tsurumachi. 1985. Purification and partial sequence of human osteoclast activating factor: identity with interleukin 1B. J. Immunol. 135:25622568.

28. Tashjian, A. H., E. F. Voelkel, M. Lazzaro, D. Good, T. Bosma, and L. Levine. 1987. Tumor necrosis factor-alpha (cachectin) stimulates bone resorption in mouse calvaria via a prostaglandin-mediated mechanism. Endocrinology. 120:2029-2036.

29. Ibbotson, K. J., S. M. D'Souza, D. D. Smith, G. Carpenter, and G. R. Mundy. 1985. EGF receptor antiserum inhibits bone resorbing activity produced by a rat leydig cell tumor associated with the humoral hypercalcemia of malignancy. Endocrinology. 116:469-471.

30. Bertolini, D. R., G. E. Nedwin, T. S. Bringman, D. D. Smith, and G. R. Mundy. 1986. Stimulation of bone resorption and inhibition of bone formation by human tumor necrosis factors. Nature (Lond.). 319:516-518.

31. Ralston, S. H., I. Fogelman, M. D. Gardner, F. J. Dryburgh, R. A. Cowan, and I. T. Boyle. 1984. Hypercalcemia of malignancy: evidence for a non-PTH humoral agent with an effect on renal tubular handling of calcium. Clin. Sci. 66:187-191.

32. Rizzoli, R., J. Caverzasio, H. Fleisch, and J. P. Bonjour. Parathyroid hormone-like changes in renal calcium and phosphate reabsorption induced by leydig cell tumor in thyroparathyroidectomized rats. Endocrinology. 119:1004-1009.

33. Doppelt, S. M., R. M. Neer, S. R. Nussbaum, D. Federico, J. T. Potts, and M. Rosenblatt. 1986. Inhibition of the in vivo parathyroid hormone mediated calcemic response in rats by a synthetic hormone antagonists. Proc. Natl. Acad. Sci. USA. 83:7557-7560.

34. Rabbani, S. A., J. Mitchell, D. R. Roy, R. Kremer, H. P. Bennett, and D. Goltzman. 1986. Purification of peptides with parathyroid hormone-like bioactivity from human and rat malignancies associated with hypercalcemia. Endocrinology. 118:1200-1210.

35. Sartori, L., E. C. Weir, A. F. Stewart, A. E. Broadus, M. Mangin, P. Q. Barrett, and K. L. Insogna. 1987. Synthetic and partially-purified adenylate cyclase-stimulating proteins from tumors associated with humoral hypercalcemia of malignancy inhibit phosphate transport in a PTH-responsive renal cell line. J. Clin. Endocrinol. Metab. In press. 